\title{
"Seym ten bez początku zaczął się, bez końca kończy się". Sejm pacyfikacyjny z 1698 roku i jego znaczenie w kontekście ewolucji liberum veto
}

\author{
Abstract \\ "This General Diet Has Begun Without a Beginning and Has Ended without \\ an End". So-called 'Pacification' General Diet in 1698 and its Meaning in the \\ Context of the Liberum Veto Evolution
}

The article presented is devoted to an interesting episode from the legal and political history of the Polish-Lithuanian Commonwealth at the end of the seventeenth century - the "breaking up" of the General Diet in 1698 by liberum veto. This particular session of the General Diet was summoned by the newly-elected king - August II, for the 'pacification' of the nation and the legitimization of his reign against the opposition that had gathered around the archbishop of Gniezno - Cardinal Michał Radziejowski in Łowicz. The Diet failed to satisfy the king's expectations. Poor attendance by envoys and senators, as well as the negative attitude of the Lithuanian delegation, caused a brief 'breaking up' of the Diet.

The author of the paper tries to show this episode, not as a political, but as a legal phenomenon, and also as an underestimated precedent in the history of old-Polish 'deliberative' democracy. He points out the insufficiency of previously known procedures of negotiation with envoys announcing their vetoes. He also emphasizes that the contradiction of the Lithuanian envoys was completely irrational, and that the acceptance shown for their demands was commonly considered to be obviously illegal. Besides this, the envoys were strictly obliged to 'break up' the Diet, which was clearly against the essence of the parliamentary mandate. However, this was not enough to reject contradiction. From this very moment any attempt to limit or restrain liberum veto was not possible.

Keywords: Polish-Lithuanian Commonwealth, General Diet, liberum veto, deliberative democracy, history of parliamentary procedures

Słowa kluczowe: Rzeczpospolita Obojga Narodów, Sejm walny, liberum veto, demokracja deliberacyjna, historia parlamentaryzmu 


\section{Uwagi wprowadzające}

Liczba monografii dotyczących sejmu walnego Rzeczypospolitej Obojga Narodów jest ogromna ${ }^{1}$, a dotychczasowy dorobek nauki daje znakomity punkt wyjścia do jeszcze bardziej dogłębnych i wieloaspektowych ocen oraz interpretacji funkcjonowania staropolskiego parlamentaryzmu². Bodaj najważniejsze dla tych badań są dziś szkice problemowe dotyczące precedensów w procedurze sejmowej. Na skutek jednorazowych zdarzeń nietypowych formułowano bowiem ad hoc interpretacje prawne mechanizmów, które uprzednio nie miały ani żadnej właściwej podstawy w prawie stanowionym czy zwyczajowym, ani zapatrywań doktrynalnych ${ }^{3}$.

Niniejszy artykuł poświęcony został takiemu właśnie precedensowi - zerwaniu sejmu pacyfikacyjnego z $1698 \mathrm{r}$. Sejm ten stanowił w sensie politycznym spektakularną klęskę świeżo koronowanego Augusta II i jego dworu - nie można go ocenić inaczej w świetle żenującej frekwencji i niezrealizowania celu - „pacyfikacji” kraju. Jak do tej pory budził zatem zainteresowanie wyłącznie jako - w ostatecznym rozrachunku raczej nieistotny - epizod w walce politycznej stronnictw saskiego i „prymasowsko-kontystowskiego" po rozdwojonej elekcji z 1697 r. ${ }^{4}$ Szlachecka opinia publiczna, zajęta

1 Por. R. Kołodziej, M. Zwierzykowski, Bibliografia parlamentaryzmu Rzeczypospolitej szlacheckiej, Poznań 2012. Zob. także przeglądy badań: R. Kołodziej, Z najnowszych badań nad parlamentaryzmem szlacheckim Rzeczypospolitej w XVI-XVII wieku, „Historia Slavorum Occidentis” 2013, t. 2 (5), s. 43-57; I. Lewandowska-Malec, Early Modern Polish Parliamentarism [16 th $-18^{\text {th }}$ C.]: Directions of the Newest Research, „Krakowskie Studia z Historii Państwa i Prawa” 2018, t. 11, z. 1, s. 35-45. Niestety, liczba prac nie zawsze przekłada się na ich jakość. Dotyczy to zwłaszcza monografii poszczególnych sejmów, których kryzys powinien, moim zdaniem, stać się przedmiotem refleksji historyków i historyków prawa. Por. np. mój szkic: T. Kucharski, „Naderwany” sejm konwokacyjny w $1696 r$. Uwagi o nieodzowności historii prawa na marginesie pracy Ewy Gąior [artykuł oddany do druku w „Czasopiśmie Prawno-Historycznym”].

2 Taki charakter mają np. prace opisujące staropolski parlamentaryzm w kontekście współczesnych mechanizmów demokracji liberalnej - I. Lewandowska-Malec, Demokracje polskie. Tradycje - wspótczesność - oczekiwania, Kraków 2013.

3 Taki charakter uzyskało, jak dotąd, raptem kilka artykułów naukowych, por. m.in. R. Kołodziej, Sejm elekcyjny w 1674 roku-precedens w procedurze sejmowej? [w:] Wokót wolnych elekcji w państwie polsko-litewskim XVI-XVIII wieku. O znaczeniu idei wyboru - między prawami a obowiazkami, Katowice 2016, s. 333-341; idem, Sejm z 22 grudnia 1693 roku, „Wieki Stare i Nowe” 2016, t. 15, s. 47-76; T. Kucharski, ,Naderwany” sejm... Cenne są prace, które analizują rozwój określonego aspektu procedury sejmowej w dłuższej perspektywie chronologicznej kilku sejmów w przełomowym dla danej instytucji czy rozwiązania okresie. Tak np. w sprawie elekcji marszałkowskich por. J. Seredyka, Elekcje marszałków poselskich za Zygmunta III Wazy [w:] Studia z dziejów Rzeczypospolitej szlacheckiej, red. K. Matwijowski, Z. Wójcik, Wrocław 1988, s. 95-112; R. Kołodziej, Elekcje marszatków poselskich w czasach panowania Jana III Sobieskiego [1676-1695] [w:] Ustrój - polityka - kultura. Studia ofiarowane Profesor Stefanii Ochmann-Staniszewskiej, red. J. Maroń, R. Kołodziej, Wrocław 2011, s. 77-94; czy też przebiegów konkluzji sejmowych: J. Choińska-Mika, Od zgody wszystkich ku jednomyślności - modus concludendi sejmów polskich za ostatnich Wazów [w:] Vetera Novis Augere. Studia i prace dedykowane Profesorowi Wacławowi Uruszczakowi, Kraków 2010, s. 72-84; I. Lewandowska-Malec, „Tragedya Conclusyey Seymowey”. Rozważania o formie i materii [w:] Społeczeństwo a władza. Ustrój, prawo, idee, red. J. Przygodzki, M.J. Ptak, Wrocław 2010, s. 253-264.

4 Zob. K. Jarochowski, Dzieje panowania Augusta II, t. I: Od śmierci Jana III do chwili wstapienia Karola XII na ziemię polska, red. K. Bartel, Oświęcim 2015, s. 104-105; B. Dybaś, Sejm pacyfikacyjny 1699 r., Toruń 1991, s. 20-21; H. Olszewski, Sejm w dawnej Rzeczypospolitej. Ustrój i idee, t. 1, Poznań 2002, s. 444; W. Konopczyński, Liberum veto. Studium porównawczo-historyczne, red. J. Lohman, Kraków 2002, s. 277; A. Rachuba, Wielkie Księstwo Litewskie w systemie parlamentarnym Rzeczypospolitej w la- 
zażartą walką o tron czy problemem obecności wojsk saskich w Rzeczypospolitej, nie zwróciła na niego szczególnej uwagi. Nie poświęcił mu wiele miejsca w swoim pamiętniku nawet przewodniczący jego obrad - Krzysztof Zawisza ${ }^{5}$. Jedynym źródłem wskazującym na rangę i znaczenie tego sejmu są diariusze sejmowe ${ }^{6}$.

Sejmowi pacyfikacyjnemu z 1698 r. z pewnością warto przyjrzeć się bliżej. Toczono na nim bowiem jeden $z$ najbardziej ostrych, a jednocześnie głębokich $i$ wielokontekstowych sporów o granice prawa wolnego sprzeciwu posła na sejmie. Więcej nawet, można zaryzykować stwierdzenie, iż $\mathrm{w}$ trakcie jego obrad podjęto mimowolnie refleksję nad samą istotą staropolskiego sejmowania i relacją między władzą sejmu a królem z jednej strony oraz między sejmem a szlacheckim społeczeństwem z drugiej.

\section{Organizacja i frekwencja}

Sejm z 1698 r. rozpoczął się, zgodnie z uniwersałem królewskim, 16 kwietnia. Otworzyło go nabożeństwo celebrowane przez biskupa płockiego - Marcina Załuskiego. Okolicznościową homilię wygłosił biskup inflancki - Mikołaj Popławski, który rozwinął w niej dwa wątki - ideę staropolskiej pacyfikacji oraz pozytywną prognozę dotyczącą nowego panowania?.

Sejm trwał jedynie trzynaście dni. Trzy były zupełnie wyłączone z obrad, z uwagi na nakazane dni świąteczne - dwie niedziele (20 i 27 kwietnia) oraz święto św. Wojciecha (we środę 23 kwietnia). W czasie pozostałych dziesięciu dni obrady nie toczyły się w zasadzie w ogóle 18 kwietnia, kiedy marszałek „solwował” sesję natychmiast po jej otwarciu. Od pierwszego dnia prace sejmu odbywały się w stanie passivitas, na skutek protestów (z 16 kwietnia i 22 kwietnia). Nie doszło zatem do przeprowadzenia wyborów marszałka ani rugów poselskich, w konsekwencji niemożliwe było udanie się posłów „na górę”, czyli odbycie wspólnej sesji z senatem.

Dotychczasowa literatura przedmiotu podkreśla niespotykanie niską frekwencję na tym sejmie. Na potrzeby niniejszego artykułu nie przeprowadzono szczegółowej kwerendy odnoszącej się do składu izby poselskiej. Wykaz posłów litewskich zawiera pamięt-

tach 1569-1763, Warszawa 2002, s. 318-319; Dz. Vitsko, Stanowisko Wiśniowieckich wobec sporów o sejm konny w 1698 roku [w:] Kultura parlamentarna epoki staropolskiej, red. A. Stroynowski, Warszawa 2013, s. 283-284. J. Wojtasik, Walka Augusta II z obozem kontystowsko-prymasowskim w pierwszym roku panowania [1697-1698], „Przegląd Historyczny” 1969, t. 60, z. 1, s. 39.

5 PKZ - [K. Zawisza], Pamiętniki Krzysztofa Zawiszy wojewody mińskiego [1666-1721], wyd. J. Bartoszewicz, Warszawa 1862, s. 194-195.

6 Korzystałem z czterech diariuszy sejmu w łącznie siedmiu kopiach. Za bardzo wartościowy należy uznać diariusz drukowany [DSP - Diariusz sejmu pacificationis zaczętego dnia 16 kwietnia 1698 r., b.m.w., 1698]. Nie ma on paginowanych stron, w konsekwencji cytując go, odwoływałem się do dat dziennych sesji. Najbardziej szczegółową relację zawiera diariusz z APT - Archiwum Państwowego w Toruniu, kat. II, VI-21, s. 185-200 [skolacjonowano go z identycznym diariuszem ze zbiorów BKC - Biblioteki Czartoryskich w Krakowie, rkps. 192]. Kolejny pochodzi ze zbiorów BO - Biblioteki Ossolińskich, rkps. 652 [został skolacjonowany z niemal identyczną wersją z BR - Biblioteki Raczyńskich, rkps. 102]. Ostatni diariusz wykorzystany w pracy to relacja ze zbiorów BKC, rkps. 192 i 521 [jest on cytowany w pierwszej wersji].

7 Por. APT, II, VI-21, s. 185. 
nik Zawiszy, ale zamieszczono tam informacje o posłach wybranych, a nie rzeczywiście przybyłych na obrady ${ }^{8}$. Kazimierz Jarochowski wskazywał na udział w sejmie piętnastu posłów ${ }^{9}$. Wiemy jednak, że część spośród nich dojeżdżała na sejm z opóźnieniem (ważni są tu zwłaszcza reprezentanci sejmików żmudzkiego i połockiego, którzy przybywszy do Warszawy 22 kwietnia, poparli protest zgłoszony 16 kwietnia). Badania Bogusława Dybasia, oparte na analizie diariusza toruńskiego, wskazują, że na początku sejmu było dziesięciu posłów koronnych i tyle samo litewskich. Do Warszawy miały zmierzać spóźnione reprezentacje sejmików mielnickiego i krakowskiego, w późniejszych dniach na pewno dotarło jeszcze dwunastu posłów litewskich ${ }^{10}$. Diariusz wrocławski podaje liczbę osiemnastu posłów obecnych na pierwszej sesji ${ }^{11}$. W tak małym gronie aktywność posłów na sesjach plenarnych była dość duża. Większość obecnych brała czynny udział w debatach, zabierając głos na forum izby. Specyfiką tego sejmu była również widoczna zgodność głosów w trakcie debat, pozostali w izbie posłowie byli zagorzałymi regalistami i koncentrowali swoje refleksje nad możliwością dalszego prowadzenia sejmu. Oczywiście nie oznaczało to zupełnego braku konfliktów czy kontrowersji ${ }^{12}$.

Wiemy, że zadziwiająco słabo wyglądała na tym sejmie frekwencja senatorów, wynosząca kilkanaście osób ${ }^{13}$. Nawet tłumaczenie, że na sejm przybyli wyłącznie zagorzali rojaliści, wydaje się niewystarczające.

\section{Treść i charakter sprzeciwu posłów litewskich}

Sejm pacyfikacyjny z 1698 r. został zerwany na skutek sprzeciwu znacznej większości posłów litewskich. Rekonstruując bieg wydarzeń z pierwszej sesji sejmu (16 kwietnia), relacje diariuszowe są zgodne. Poseł witebski nazwiskiem Czaplic miał zabrać głos

8 Wykaz ten zawiera 36 nazwisk, PKZ, s. 194-195.

9 K. Jarochowski, Dzieje..., s. 104. Tak również W. Konopczyński, Liberum..., s. 277.

10 B. Dybaś, Sejm..., s. 40.

11 BO, 652, k. 149v. Inny diariusz wskazuje, że posłów było „nie wielu”. Autor relacji, precyzując, szacował liczbę posłów na „circa 30”, BKC, 192, s. 135.

12 Ciekawy epizod miał miejsce 26 kwietnia. Los sejmu był już wówczas przesądzony, jednakże reprezentacja powiatu starodubowskiego i część posłów powiatu lidzkiego zgłosiła sprzeciw wobec jego zakończenia. Wywołało to konflikt w łonie reprezentacji powiatu lidzkiego. Anonimowy i niedoświadczony parlamentarzysta [nazwany w relacji po prostu „młodzikiem”] przerywał tok wypowiedzi starszemu koledze [nazwanemu ,veteranem”]. Uczynił to niezbyt uprzejmie [zgodnie z relacją - ,dure et scommatice przymówił”]. Odpowiedź była stanowcza: „mu veteran krótko a węzłowato odpowiedział w ten sens, raczey tu disce puer virtutem ex me bo gdym ia posłował toś ty ieszcze gdzieś snował”. Ciekawa jest reakcja młodego polityka, który przestraszył się innych posłów gotowych stanąć w obronie bardziej godnego i starszego parlamentarzysty: ,interim Imć P. Marszałek skoczył ad mediandum, bo postrzegł się, że na exortę zanosiło większą przeciwko panu starodubowskiemu". Ostatecznie młody poseł wycofał się milcząco z konfrontacji, bojąc się otwartego konfliktu z całą izbą i bardziej wpływowym kolegą posłem, który mógł zaszkodzić mu w dalszej karierze - „zamilkł P Poseł Starodubowski młodzik y skonfundowany oczy w ziemię wlepił”, BR, 102, k. 321v-322. Omawiane wydarzenie wydaje się mieć duże znaczenie świadczące o istnieniu pewnej wewnętrznej hierarchii wśród posłów na sejmach przełomu XVII i XVIII stulecia.

13 Diariusz krakowski podaje, iż na początku sejmu zebrał się „,senat bardzo rzadki”, BKC, 192, s. 135. Diariusz toruński pozwala zidentyfikować około 15 senatorów, w tym 13 obecnych na mszy inauguracyjnej, APT, II, VI-21, s. 185-200. 
zaraz po zagajeniu obrad przez marszałka i zgłosić sprzeciw, który już w formie należy uznać za oryginalny. Poseł nie podjął dyskusji, zrezygnował również z typowych dla staropolskiego parlamentaryzmu form wypowiedzi - długiej mowy wygłaszanej z pamięci albo krótkiego i spontanicznego oświadczenia o sprzeciwie. Zamiast tego odczytał w całości przywiezioną przez siebie instrukcję, którą jeden z diariuszy charakteryzuje jako „szeroce napisaną”" ${ }^{14}$. Zabieg ten powtórzyło następnie jeszcze co najmniej czterech posłów litewskich. Głębsze uzasadnienie protestu dał poseł Krzysztof Zenowicz, który uzupełniając odczytaną instrukcję, skonstatował, że Litwini „nie tego Seymu chcą, ale konnego, ponieważ tak wiele Ichmościów iest przeciwnych Coequacyey"15.

Sprzeciw Litwinów należy oczywiście oceniać z perspektywy konfliktów politycznych i społecznych. Wielkie Księstwo znajdowało się w tym czasie w fazie silnej polaryzacji między Sapiehami a ruchem szlacheckim tzw. koekwacyjnym ${ }^{16}$. Przez całe bezkrólewie szlachta litewska domagała się przy tym uchwalenia zrównania prawnego Litwy i Korony, czyli tzw. koekwacji praw ${ }^{17}$. Skutkowało to przyjęciem stosownego aktu prawnego przez sejm elekcyjny, aprobowanego odpowiednią uchwałą sejmu koronacyjnego z 1697 r. oraz konstytucją sejmu pacyfikacyjnego z $1699^{18}$. Mimo to Litwini uznali, że konieczne jest zwołanie sejmu konnego egzorbitancyjnego (tj. odbywanego w trybie pospolitego ruszenia, w polu, $\mathrm{z}$ bronią $\mathrm{w}$ ręku), by zagwarantować ostateczne potwierdzenie i wprowadzenie w życie uchwały z $1697 \mathrm{r}^{19}$

Podejmując refleksję na temat omawianego sprzeciwu z sejmu 1698 r., nie należy się jednak koncentrować na samym żądaniu zwołania sejmu konnego. Był to w tym czasie bardzo popularny postulat polityczny, niezwiązany ściśle z koekwacją i bezkrólewiem po śmieci Jana III. Na sejmie pacyfikacyjnym z 1698 r. konflikt toczył się jednak nie o to, czy w ogóle zwoływać sejm konny, ale czy powinien on zastąpić sejm pacyfikacyjny (tzn. czy dopuszczalne jest zerwanie sejmu pacyfikacyjnego tylko dlatego, że nie stanowi realizacji postulatu zwołania sejmu konnego ${ }^{20}$. Za najistotniejsze należy zatem

14 DSP, 16.04. Odczytywanie całości instrukcji potwierdzają: BKC, 192, s. 136; BO, 652, k. 149v. Powoływanie się na instrukcje było oczywiście częste, ale czytanie ich w izbie, zwłaszcza w całości, nie było przyjętą praktyką, por. R. Kołodziej, ,, Ostatni wolności naszej klejnot”. Sejm Rzeczypospolitej za panowania Jana II Sobieskiego, Poznań 2014, s. 434-435.

15 Diariusz wspomina jeszcze o ,inszych punktach”, bez doprecyzowania, o jakie kwestie chodziło, DSP, 16.04. 22 kwietnia z opóźnieniem przybyli na sejm kolejni kontradycenci, którzy poparli wcześniejsze protestacje. Jeden z posłów żmudzkich ,rzekł, że imieniem Xięstwa swego ni na co pozwolić nie może, ieno się konnego seymu domawiać powinien”, DSP, 22.04.

16 Por. A. Rachuba, Wielkie Księstwo..., s. 318 i n. O odsłonie tego sporu w okresie bezpośrednio poprzedzającym sejm z 1698 r. i w jego trakcie pisze Dz. Vitsko, Stanowisko Wiśniowieckich..., s. 269-284.

17 Por. J. Malec, Coaequatio Iurium Stanów Wielkiego Księstwa Litewskiego z Koroną Polska z 1697 r., „Studia Baltico-Slavica” 1979, t. 12, s. 203-215.

18 VL-Volumina Legum, wyd. J. Ohryzko, t. V, Petersburg 1859, s. 420-421.

19 Wszystkie diariusze podkreślają, że sejm konny był podstawowym żądaniem litewskich kontradycentów. Tylko diariusz krakowski wskazuje na używanie zamiennie pojęć „,sejm konny” i „,sejm egzorbitacyjny” - Litwini mówili więc np. z jednej strony, że „seym miał być exorbitantiarium a nie pacificationis”, a z drugiej podkreślali, że w imieniu swoich województw proszą króla o zwołanie takiego sejmu, nazywając go „konnym”, BKC, 192, s. 136. Szerzej o idei sejmu konnego i jego krytyce: T. Kucharski, Instytucja egzorbitancji $w$ systemie prawnoustrojowym Rzeczypospolitej Obojga Narodów, Toruń 2014, s. 286-290. Tam starsza literatura.

20 Instrukcje koronne z 1698 r. również zawierały postulaty zwołania sejmu konnego, ale po sejmie pacyfikacyjnym w zgodzie z obowiązującymi regułami. Dla przykładu: sejmik podolski w swojej krótkiej 
uznać postawienie tego żądania przez Litwinów wbrew recesowi sejmu koronacyjnego i wbrew uniwersałowi królewskiemu zwołującemu sejm.

Sprzeciw sejmowy z 1698 r. stanowił zatem zakwestionowanie prawidłowości formy zwołania sejmu przez króla. Był w zasadzie nie tyle aktem zerwania sejmu, co żądaniem uznania go za nieważny. Ma to bardzo daleko idące konsekwencje dla rozumienia istoty staropolskiego liberum veto. Jak wskazują dogłębne badania polskiej historiografii (m.in. świeże ustalenia Roberta Kołodzieja), legalna kontradykcja sejmowa w dawnej Polsce zawsze powinna była wyrażać negatywne stanowisko samego posła (czy też jego sejmiku) w jakieś sprawie. Mógł się on koncentrować albo na kwestiach proceduralnych (np. braku akceptacji dla prolongaty), albo merytorycznych (konkretnego projektu konstytucji proponowanego na sejmie). Sprzeciw mógł również stanowić wyraz presji - podana przez kontradycenta przyczyna jego podniesienia była wtedy jedynie pretekstem, by zatamować obrady i ,zaszantażować” izbę poselską. Celem było tu wymuszenie na posłach zajęcia się jakąś inną sprawą czy spełnienia innego postulatu. Zdarzało się oczywiście, że sprzeciw był wprost motywowany bieżącą polityką, bez ścisłego związku z obradami sejmowymi. Wszystkie te rodzaje sprzeciwów miały jednak dwie cechy wspólne. Po pierwsze, kontradykcja ,przy prawie” wymagała uzasadnienia, choćby było ono czysto fasadowe. Założeniem było tu albo wymuszenie podjęcia określonych decyzji przez sejm, albo zapobieżenie ich podjęciu (ewentualnie opór wobec przeciągania obrad). Po drugie, założeniem sprzeciwu było czasowe uniemożliwianie dalszej pracy sejmu, z uwagi na jakąś obiektywną przyczynę (znajdującą pokrycie w instrukcji sejmikowej), której usunięcie miało pozwolić na dalszą pracę sejmu. Oba te założenia obowiązywały formalnie zawsze, nawet jeśli prawdziwe motywacje posła miały charakter korupcyjny (czy wynikały z podległości klientalnych), a prawdziwym celem sprzeciwu było doprowadzenie do zakończenia prac sejmu ${ }^{21}$.

Na sejmie 1698 r. te reguły zostały odrzucone. Stanowisko sejmików litewskich nie pozostawia tu jakichkolwiek wątpliwości. Posłowie powinni byli natychmiast po przybyciu „sejm rwać y invalidować nie wchodząc w ullas questiones" ${ }^{22}$. Najszersze uzasadnienie tak ujętego charakteru mandatu zawarto w relacji toruńskiej, według której poseł Zenowicz „,rzeźwym głosem praecautią uczynił, że y zaczynać seymu niedopuścić miał urgentibus articulis instructiey powiatu swego, że go y drugich Ichmw rigorissime obstrinxit fervor populi, iż non tutum y wracać się im do Braci bez zepsowania seymu

instrukcji z 25 marca 1698 r. nakazywał: ,panowie posłowie nasi o tenże sejm konny upraszać będą imieniem całego województwa podolskiego". Uzasadnieniem jest tu z jednej strony przychylenie się do woli innych województw, z drugiej zaś fakt, że szlachta podolska „lubo jęczy w pogańskich więzach, ipsa eius exhorret parthia casus, przecie in zelo boni publici i dostojeństwa Najjaśniejszego Majestatu indefessum nosi vigorem", Akta sejmiku podolskiego in hostico 1672-1696, wyd. J. Stolicki, Kraków 2002, s. 217. Postulaty sejmu konnego próbowali też wyzyskać opozycjoniści zebrani na zjeździe łowickim w lutym 1698 r., m.in. posłowie sandomierscy domagali się, ,aby seym konny exorbitantiarum był złożony”, BKC, 192, s. 44. H. Olszewski, Sejm..., s. 444-445, opisuje szerzej spory o sejm konny w latach 1698-1703.

${ }_{21}$ R. Kołodziej, „Ostatni wolności naszej klejnot”..., s. 428-432. Autor wymienił cztery rodzaje protestów z uwagi na ich ,zakres”: zakwestionowanie jednego konkretnego projektu, zakwestionowanie wszystkich projektów z wyjątkiem niektórych, protest przeciwko określonym „czynnościom” sejmowym, protest warunkowy (czyli groźba protestu ze zgłoszeniem konkretnego żądania).

22 BO, 652, k. 149v.

Artykuły - Articles 
pacificationis na pirszym dniu"23. To absolutnie najważniejsza wypowiedź, którą poseł formułuje, zresztą z widocznymi i zarejestrowanymi przez autora relacji emocjami. Kontradycenci tłumaczyli osobno w czasie prywatnej audiencji u króla, że złożyli na sejmikach osobną przysięgę, iż doprowadzą do zerwania sejmu pierwszego dnia obrad $\mathrm{i}$ „muszą wolą pryncypałów swoich, to iest Szlachty w domach pozostałey pełnić, którzy ich tak obowiązali confiscatione bonorum et honorum a nawet discrimine vitae"24.

Sejm 1698 r. jest w tym kontekście zupełnie rewolucyjny. Część posłów przywiozła bowiem na niego instrukcje, w których nie znalazło się upoważnienie do zerwania sejmu czy nakaz jego zerwania w określonej sytuacji albo pod określonymi warunkami. Znajdował się tu bezwzględny i bezwarunkowy nakaz zerwania sejmu niezależnie od jakichkolwiek czynników czy okoliczności. Towarzyszyło temu zakwestionowanie samej formy odbywania sejmu, a kontradycenci zostali dodatkowo „zmotywowani” do respektowania stanowiska sejmiku szczególną przysięgą. Mandat poselski nie otwierał tu więc drogi do wykorzystania sprzeciwu w celu wywarcia presji na sejmujących albo załatwienia określonych postulatów na sejmie. Przedmiotem protestacji nie była tu określona sprawa, stosunek sejmiku czy posła do określonego problemu merytorycznego czy proceduralnego. Instrukcja stwierdzała po prostu nieprawidłową formę sejmu i żądała właściwie jego unieważnienia, wbrew recesowi krakowskiego sejmu koronacyjnego (przewidującemu odbycie sejmu w formie tradycyjnej, a nie konnej) oraz wbrew uniwersałowi zwołującemu sejm (a więc wbrew utrwalonym normom prawa zwyczajowego, według których to przecież król był wyłącznie uprawniony do zwoływania sejmu i to wyłącznie on, po konsultacjach z senatorami, decydował, czy, kiedy i w jakiej formie należy go zwołać).

Czy forma i charakter sprzeciwu z 1698 r. powinny być postrzegane w kategoriach sejmowego precedensu? Wiemy, że szlachta uznawała niekiedy nieprawidłowość formy zwołanego sejmu - dotyczyło to zwłaszcza sejmów nadzwyczajnych w czasach Zygmunta III i Władysława IV. Najbardziej ekstremalnym środkiem reakcji szlacheckiej opinii publicznej było tu jednak zbojkotowanie sejmu w 1637 r. przez zgromadzony w Środzie Wielkopolskiej sejmik poznańsko-kaliski. Nieobecność posłów jednego sejmiku nie zablokowała jednak przeprowadzenia sejmu i nie dawała podstaw do kwestionowania prawomocności jego uchwał. Standardową reakcją na nielegalne zwoływanie

23 APT, II, VI-26, s. 187. Treścią mandatu poselskiego było zatem, ,żeby in primo termino inwalidować ten seym a o konny upraszając JKMci”, ibidem, s. 186. Zgodnie z oświadczeniem jednego z kontradycentów ,Inhaerendo tedy Instrukcyi braci swoich protestował się niepozwalaiąc, ani na akt seymu, ani na sessye prowincyonalne, ale o seym konny upraszając", BO, 652, k. 152v. Powołując się na swoje instrukcje, kontradycenci przytaczali stanowczy nakaz sejmiku dla posłów, ,ażeby na taki seym nie pozwalali, ani mu activitatem nie przyznawali”, BKC, 192, s. 137. Inna relacja wskazuje, że zgłaszający sprzeciw poseł Czaplic deklarował, iż ,tu przyjechał nie do seymowania, ale do zerwania seymu”, DSP, 16.04.

24 DSP, 20.04. Jeszcze pełniejszą wersję przysięgi przytacza diariusz toruński, według którego poseł Czaplic powołał się na ,jurament, że ieżeli te swoie desideria pro Bono Publico wnoszą to tak im Pani Boże dopomóż, a ieżliby niesłusznie, aby ich Bóg y na duszy y na ciele pokarał. To ieszcze z instructiey czytaiąc, że obligowani są nie tylko juramentem, ale poena infamiae et confiscatione bonorum y to nie tylko suismet personis, ale in succesoribus", APT, II, VI-21, s. 186. Por. BKC, 192, s. 137. Niewątpliwie presja spoczywająca na posłach była ogromna, świadczy o tym Manifestatia Woiewództw y Powiatów W[ielkiego] K[sięstwa] L[itewskiego] A[nno] D[omi]ni 1698, AGAD - Archiwum Główne Akt Dawnych, AR - Archiwum Radziwiłłów, dz. II, nr 1850, s. 1-6. W tekście uchwały przyjętej w trakcie trwania sejmu pacyfikacyjnego w kwietniu 1698 r. widoczne są obawy o utrzymanie zdobyczy koekwacji i uznanie sejmu konnego za remedium. 
przez króla sejmów nadzwyczajnych było z zasady godzenie się szlachty z rzeczywistością. W świetle braku możliwości zakwestionowania uniwersału zwołującego sejm szlachta domagała się po prostu reasumowania konstytucji o niedopuszczalności zwoływania sejmów nadzwyczajnych bez uprzedniej uchwały sejmu i jej respektowania w przyszłości ${ }^{25}$. Wydaje się zatem, że wybór posła (nawet po 1652 roku), tylko i wyłącznie po to, żeby nie dopuścił on do przeprowadzenia zwołanego przez króla sejmu, nie mieścił się w istocie staropolskiego mandatu sejmowego. A jednak sprzeciw oparty na tak skonstruowanej instrukcji nie został zakwestionowany jako z gruntu nielegalny. Staropolski parlamentaryzm „,deliberacyjny” okazał się bezradny wobec sytuacji, w której treścią mandatu poselskiego było niedopuszczenie do odbycia sejmu. Okazało się, że jedynym i wyłącznym celem udziału parlamentarzysty w obradach sejmu walnego mogło być zagwarantowanie, że nie dojdą one do skutku.

\section{Procedura "zarządzania" sprzeciwem}

Żeby prawidłowo odpowiedzieć sobie na pytanie, dlaczego doszło do zaakceptowania tak osobliwego w formie i treści sprzeciwu sejmowego z 1698 r., należy prześledzić funkcjonowanie tradycyjnych sejmowych procedur związanych z ,zarządzaniem” sprzeciwem. Chodziło o zestaw procedur negocjacji z kontradycentami, w celu uzyskania cofnięcia sprzeciwu i przywrócenia sejmowi activitas. Zgodnie z utartym zwyczajem parlamentarnym główna rola przypadała tu marszałkowi poselskiemu. To właśnie on osobiście winien był powstrzymywać kontradycentów przed opuszczeniem sali obrad, próbując ich ,zatrzymać w drzwiach” i przekonać do powrotu na miejsca. W razie fiaska tych zabiegów to jego obowiązkiem było wysyłanie deputacji do kwater protestujących, by podjąć z nimi negocjacje. To również on był odpowiedzialny za morale i utrzymanie dyscypliny wśród posłów, którzy z głosem pasywnym pozostawali w izbie poselskiej ${ }^{26}$.

W dniu rozpoczęcia sejmu pacyfikacyjnego - 16 kwietnia 1698 - przewodnictwo obrad przejął marszałek starej laski, Krzysztof Zawisza. Obejmując kierowanie obradami, chciał on, zgodnie z konstytucją 1690 r., natychmiast przystąpić do wyborów nowego „dyrektora” izby. Sprzeciw Litwinów uniemożliwił jednak podjęcie jakichkolwiek czynności relewantnych prawnie, w tym wyboru nowego marszałka. Zawisza ,utknął” więc na swoim stanowisku, którego w ogóle nie chciał sprawować. Diariusze pozostawiają ślady zrezygnowania i obaw marszałka, niezbyt dobrze czującego się w roli, którą wyznaczyły mu okoliczności - ratującego sejm za wszelką cenę ${ }^{27}$. Znamienne, że do-

25 Szerzej o tym problemie pisze P. Paradowski, W obliczu ,naglych potrzeb” Rzeczypospolitej: sejmy ekstraordynacyjne za panowania Władysława IV Wazy, Toruń 2005, s. 92-95.

26 Szerzej piszę na ten temat - T. Kucharski, ,Naderwany” sejm...

27 Ślady tej rezygnacji są widoczne w wypowiedziach rozsianych w relacjach diariuszowych. Mówił np. „Ja upraszam, abyście się WMPanowie ab hoc onere Directorio uwolnić chcieli, żebym przez tę laskę u WMPanów nie zasłużył na niełaskę", BO, 652, k. 150. W innej relacji z 19 kwietnia marszałek zauważył, że kontradycenci ,iuż się w drogę zabierali [...] a zatym próżno czas pro et contra zabieramy”, BKC, 192, s. 140. Także pełna podniosłego żalu mowa pożegnalna, nawet jak na standardy barokowego języka i ekspresji, zawiera ogromny ładunek emocjonalny rozczarowania marszałka.

Artykuły - Articles 
świadczony i poważany parlamentarzysta, jakim był Zawisza, pozwalał sobie na bardzo emocjonalne reakcje w czasie sejmu, w tym również na wycieczki personalne, co nie wróżyło dobrze odgrywaniu przez niego roli czynnika wypracowującego konsensus ${ }^{28}$.

Opisując przebieg obrad z 16 kwietnia, relacje są dość zgodne, wskazują na podjęcie przez marszałka próby zatrzymania kontradycentów w izbie ${ }^{29}$. Jednakże niemal natychmiast po niepowodzeniu tych symbolicznych działań Zawisza ,chciał już pożegnać izbę poselską". Oznaczało to rezygnację z wysyłania specjalnej deputacji negocjacyjnej do „gospód” sprzeciwiających się posłów ${ }^{30}$. Ostatecznie powołano tę deputację, ale wyłącznie w wyniku stanowczej presji pozostałych w izbie posłów-regalistów ${ }^{31}$. Znamienne, że gdy 17 kwietnia deputacja złożyła relację ze swej misji (z której wynikało, że kontradycenci stanowczo odmawiają cofnięcia sprzeciwu) marszałek miał nawet nie wypełnić zwyczajowego obowiązku wyrażenia podziękowań dla członków deputacji za ich pracę. Tę rolę miał przejąć na siebie lider regalistów - referendarz koronny Stanisław Szczuka ${ }^{32}$. Świadczy to niewątpliwie o rezygnacji Zawiszy z jakichkolwiek starań o utrzymanie sejmu.

Po zakończeniu relacji deputacji, niemal natychmiast „się tedy IMość Pan Marszałek chciał brać do pożegnania Izby"33. Tylko zawziętość i determinacja Stanisława Szczuki oraz jego adherentów przekonały marszałka, „aby się do iakiego czasu z oddaniem laski zatrzymał, a że ieszcze ultima hora przynieść może Izbie Poselskiey pożądaną activitatem" ${ }^{34}$. Marszałek uległ presji - chciał zakończyć sejm, „,ale multis renitentibus zatrzymał się" 35 .

Zawisza nie walczył o przetrwanie sejmu, uznając dalsze starania za bezcelowe. „Podziękować y położyć laskę" chciał więc na zakończenie bezowocnej sesji 19 kwietnia, „ale go wszyscy Imć prosili aby nią dyrygował" ${ }^{36}$. Zagajając sesję dnia 21 kwietnia, oddał posłom decyzję co do dalszych losów sejmu, sam sugerował jednak zakończenie prac z uwagi na fakt, że ,iuż nie masz żadney o Seymie nadziei” ${ }^{37}$. 24 kwietnia, po prze-

28 Gdy marszałek dowiedział się, że na sesję 17 kwietnia nie stawił się poseł Stefan Łuskina, miał powiedzieć: „nie dbamy o łuskowiny, kiedy same orzechy mamy”. Co prawda, jak podkreśla autor relacji, Zawisza wygłosił tę opinię: ,privatim in murmure discursu”, APT, II, VI-21, s. 188. Nie zmienia to jednak faktu, że zachowanie to musiało dojść do uszu kontradycentów i nie mogło się przyczynić do poprawy atmosfery ani do efektywności negocjacji o wycofanie sprzeciwu.

29 Diariusz toruński wskazuje, że marszałek próbował rozmawiać z posłami, ,których [...] persvasią zmiękczyć nie mógł”. Z kolei relacja wrocławska sugeruje, i to drobną wzmianką, że marszałek próbował zatrzymać posłów przed opuszczeniem izby. Notatka wspomina jedynie, że kontradycenci w wielkim tumulcie wyszli, nie dając się [...] Marszałkowi swoiemu utrzymać [...]”, BO, 652, k. 149v.

30 BO, 652, k. 149v.

31 Powołanie deputatów stwierdzają wszystkie diariusze. O tej procedurze piszę szerzej w pracy: T. Kucharski, „,Naderwany” sejm...

32 BKC, 192, s. 139.

33 DSP, 17.04. Podobnie w BO, 652, k. 150: „Po uczynioney relacyey dziękował ImPan marszałek inferendo, iezeliby stantibus tak wielu Ichmciów contradictionibus formari miały perturbationem Reiplcae consiliu. Ja upraszam, abyście się WMPanowie ab hoc onere Directorio uwolnić chcieli [...]”. Tylko diariusz toruński sugeruje wątpliwości marszałka, który miał zostawić tę decyzję posłom, APT, II, VI-21, s. 189.

34 BO, 652, k. 150-150v. W innej relacji ,upraszał [Szczuka - TK] Imć P. Marszałka aby laski nie dał, ale nią dyrygował y głosy rozdawał na co były głosy: zgoda”, BKC, 192, s. 139.

35 BO, 652, k. 150.

36 BKC, 192, s. 140.

37 DSP, 21.04. 
kazaniu izbie negatywnej decyzji króla co do zwołania sesji prowincjonalnych, marszałek znów wskazał na niecelowość dalszych obrad i zaapelował o ich zakończenie, choć oczywiście ostateczną decyzję po raz kolejny formalnie pozostawił w rękach posłów ${ }^{38}$. Jeszcze na przedostatniej sesji sejmowej, 26 kwietnia, podjął Zawisza próbę przekonania posłów do rozejścia się. Usprawiedliwiał się przy tym, tłumacząc, że zakończenia prac sejmowych „nie dlatego sobie życzył, żeby mu to było molestum służyć Ichm ale że nadaremna de die in diem procrastynacya seymowania, absq[ue] activitate emolumenti obiecuie, satius expediret żegnać Izbę Poselską" ${ }^{39}$. Taka argumentacja spotkała się ze zrozumieniem większości izby, „ImP. Marszałek iednostayney deklaracyey nie mógł otrzymać $[\ldots]$ solvovał sessyą do poniedziałku" ${ }^{\prime 40}$.

Postawa Zawiszy - umiarkowanego i rozsądnego polityka - wydaje się zrozumiała. Sejm, przy nikłej frekwencji i stanowczych sprzeciwach Litwinów, rzeczywiście nie miał jakichkolwiek szans powodzenia. Marszałek sejmowy (i to tylko „starej laski”) chciał w sposób naturalny uniknąć niepotrzebnego i jałowego przeciągania obrad. Takie podejście nie zadowalało jednak stronnictwa regalistów. Zapewne i oni zdawali sobie sprawę z nikłych szans sejmu na sukces, jednak klęska sejmu równała się przecież klęsce nowego monarchy i jego adherentów, kosztem opozycji zorganizowanej w ramach rokoszu łowickiego. W tym należy upatrywać genezy twardego i konsekwentnego torpedowania wszelkich prób zakończenia sejmu. Szczególne znaczenie miała błyskotliwa przemowa Stanisława Szczuki z drugiego dnia obrad. Dokonał on wówczas brawurowej interpretacji zasad sejmowania - nie tylko konstytucji z 1690 r., ale również prawa zwyczajowego w tym zakresie - stwierdzając, że dla uznania pełnej skuteczności sprzeciwu zgłoszonego w izbie poselskiej (a więc i jego skutku w postaci zakończenia prac sejmu przed czasem) konieczne jest upłynięcie terminu rozpoczęcia konkluzji sejmowej:

Replikował [...], że to bydź nie może lubo jus vetandi ma swoię vim et robur, iednakże w tey izbie antiqua praxi et de iure et de consuetudine iest nierwać seymu abo raczey niewyieżdżać z protestatiami, ale siedzieć activitatem hamuiąc y tylko passive pozwalając mówić, aż do onych pięciu dni, kiedy na górę izba poselska wchodzi złączyć się z senatem. A po onych piąciu dniach dopiro żegnać Króla $\mathrm{Im}^{41}$.

Konsekwencją sprzeciwu zgłoszonego w izbie miał być jedynie stan passivitas. „Starodawna praktyka, prawo i zwyczaj” przesądzały o tym, że posłowie, mimo sprzeciwu, musieli uczestniczyć w obradach do dnia konkluzji, licząc na jego cofnięcie.

Rola Szczuki jako przywódcy regalistów na sejmie była niekwestionowana. Zapewne zostałby on marszałkiem sejmowym, gdyby sejm zachował activitas i zdołał dokonać wyboru $^{42}$. Sprzeciw Litwinów zamknął jednak drogę do takiego rozwiązania, a na stanowisku marszałka pozostawał niechętny utrzymaniu sejmu za wszelką cenę Zawisza. Powstał zatem dylemat natury formalnej - Szczuka nie posiadał jakiejkolwiek legitymacji do prowadzenia negocjacji z kontradycentami. Nieuniknioną koniecznością było

38 Ibidem, 24.04.

$39 \mathrm{BO}, 652, \mathrm{k} .153$.

40 Ibidem.

41 APT, II, VI-21, s. 188. Por. BKC, 192, s. 138.

42 Ostatecznie uzyskał on przecież tę godność na kolejnym sejmie pacyfikacyjnym w 1699 r., B. Dybaś, Sejm..., s. 132-148. 
więc znalezienie czynnika alternatywnego wobec marszałka izby, który mógł formalnie przejąć jego rolę i podjąć zadanie przekonania protestujących Litwinów. Ze względu na oczywisty autorytet instytucjonalny oraz pozycję osobistą wybór padł na świeżo koronowanego monarchę - Augusta II.

Już w dniu złożenia protestu monarcha zlecił wstępne negocjacje z kontradycentami swoim ,prywatnym posłom" ${ }^{\prime 4}$. To oryginalne zachowanie; co do zasady monarchowie nie ingerowali w negocjacje, zwłaszcza na tak wczesnym etapie. Osobiście król zaangażował się w ratowanie sejmu w niedzielę 20 kwietnia. Przygotowujący się do powrotu do domów posłowie-kontradycenci mieli postanowić oficjalnie pożegnać króla ${ }^{44}$. To prawdopodobnie eufemizm autora relacji, audiencja u króla raczej nie była własną inicjatywą kontradycentów. To sam August musiał zażądać ich obecności. Regaliści i otoczenie królewskie liczyli zapewne na to, że osobista rozmowa z monarchą przekona protestujących do wycofania sprzeciwu, albo chociaż pozostania w Warszawie (co dawałoby jeszcze nadzieję na uratowanie sejmu).

W trakcie audiencji król bardzo stanowczo wyraził żądanie, żeby posłowie wycofali swój sprzeciw. Sugerował, że zgodnie z jego wiedzą „Posłowie Ziemscy miewają zawsze plenariam potestatem consulendi et concludendi" "'5. Opinia ta była oczywiście nieprawdziwa, z czego król z pewnością zdawał sobie sprawę. Miała ona jednak za zadanie wywarcie bezpośredniej presji na posłów. Kontradycenci bronili się twierdzeniem, że wiąże ich instrukcja, nakazująca im bezwzględnie zerwać sejm. Odpowiedziała im na to grupa zaufanych królewskich senatorów, niestety niewymienionych z nazwiska i godności. W mowie (z pewności przygotowanej już wcześniej) obszernie i merytorycznie skrytykowali oni instrukcje Litwinów ${ }^{46}$. Kontradycenci nie ulegli jednak presji i nie cofnęli sprzeciwu, plan zatem zupełnie się nie powiódł. Sam mechanizm organizacji osobistej u króla $\mathrm{z}$ udziałem senatorów, w celu wywarcia presji na protestujących, jest jednak bardzo ciekawy.

Na koniec spotkania kontradycenci przedłożyli monarszą prośbę wystawienia formalnego pisma, które mogliby przedstawić na sejmikach. Nie mamy w tym zakresie bliższych informacji, ale chodziło prawdopodobnie o potwierdzenie wykonania przez posłów instrukcji i złożenia na ręce króla żądania zwołania sejmu konnego. Mimo negatywnego nastawienia do stanowiska kontradycentów, „cicho rozmówiwszy się z Panami Senatorami”, August II zgodził się na wydanie takiego dokumentu. Wobec konsekwentnego oporu Litwinów król nie zdecydował się na otwartą konfrontację. Przyjął do wiadomości ich stanowisko oraz zgodził się na dodatkowy postulat - wystawienie osobnego pisma. Prawdopodobnie chciał wykazać się koncyliacyjną postawą wobec sejmików w perspektywie kolejnej kampanii przedsejmowej.

$\mathrm{W}$ dalszych dniach król nie angażował się już w takim stopniu w negocjacje, z uwagi na przesądzony już los sejmu. 21 kwietnia nie znalazł więc czasu dla marszałka Zawiszy,

43 BO, 652, k. 149v.

44 Co ciekawe, o tym wydarzeniu informuje tylko diariusz drukowany: „[...] przyszli Ichmość Panowie Protestanci iuż podróżni, chcąc żegnać Króla Iego Mości, wziął ich Król do pokoiu swego, traktował z niemi [...]", Diariusz, 20.04. Inne diariusze o nim nie wspominają, np. diariusz toruński zostawia jedynie relację z obecności króla na mszy świętej w kościele św. Jana, APT, II, VI-21, s. 193.

45 DSP, 20.04.

46 Argumenty merytoryczne senatorów zaprezentowałem w kolejnym podrozdziale. 
który został zobowiązany przez regalistycznych posłów do poproszenia monarchy o zwołanie sesji prowincjonalnych ${ }^{47}$. Dopiero 24 kwietnia August podjął ostatnią, typowo już symboliczną próbę ocalenia obrad, wysyłając deputację senatorów, by wyrazili ubolewanie $\mathrm{z}$ powodu braku sesji w stanach złączonych. Jak wiadomo, pierwsze w trakcie sejmu przyjście posłów do senatu („,na górę”) wymagało załatwienia rugów, wybrania marszałka i zgody posłów na przejście do tego etapu obrad. Z reguły król i senat byli raczej wstrzemięźliwi w wywieraniu presji na posłów, szczególnie oficjalnej - za pomocą deputacji ${ }^{48}$. Na omawianym sejmie $1698 \mathrm{r}$. taka deputacja z bardzo sztywnym stanowiskiem przybyła do izby poselskiej, co ciekawe, w momencie, w którym marszałkowi prawie udało się przekonać obecnych posłów do zakończenia obrad ${ }^{49}$. Według jednej z relacji występujący w imieniu króla i senatu biskup inflancki tłumaczył obecność w Polsce wojsk saskich ${ }^{50}$. Według innego diariusza biskup ,przemowę miał omnem pollicendo conatum sollicitudinem et liberalitatem JKMci ad pacificandam Remp" "51. To, co rzuca się w oczy, to moment tej ostatniej interwencji królewskiej. Mamy tu do czynienia z zachowaniem czysto taktycznym. Monarcha chciał ostatni raz zaakcentować swoje zaangażowanie i pozostawić wrażenie, że uczynił wszystko, by zapobiec zerwaniu sejmu, choć jego los i tak był już przesądzony. W kolejnym dniu król rozdał jeszcze wakanse, znów okazując symbolicznie szacunek dla praw Rzeczypospolitej. Nie próbował już ratować sejmu, ale tylko wyciągnąć z niego korzyści propagandowe.

$\mathrm{Z}$ punktu widzenia nauki historii prawa i oceny proceduralnej rezultatem specyficznej konfiguracji politycznej była rezygnacja marszałka sejmu z naturalnej roli negocjatora z kontradycentami. Konsekwencję stanowiła próba wykorzystania instytucjonalnego autorytetu monarchy dla uratowania sejmu. Próba ta, choć zakończona fiaskiem, jest niewątpliwie interesującą anomalią w procedurze sejmowej.

\section{Postawa regalistów wobec sprzeciwu}

$\mathrm{Na}$ koniec warto poświęcić parę słów zaprezentowaniu postawy większości obecnych na sejmie posłów i senatorów, pragnących kontynuacji pracy sejmu, pomimo sprzeciwu Litwinów i bierności marszałka Zawiszy.

Szczególnie interesująca była dogłębna i staranna prawniczo argumentacja, do której odwołali się senatorowie w trakcie wspomnianej prywatnej sesji u króla. Mieli oni pełną świadomość, że nie mogą otwarcie zarzucić formalnej nieważności samemu sprzeciwowi. Nie należało to do ich kompetencji, uznanie legalności sprzeciwu leżało bowiem wyłącznie w gestii marszałka i izby poselskiej. W konsekwencji, nie kwestionując samego sprzeciwu, próbowali podważyć jego merytoryczne fundamenty. Zakwestionowali

47 DSP, 22.04; BO, 652, k. 151v. Diariusz toruński podaje informację o sesji w pokojach królewskich, ale dnia 21 kwietnia rano, por. APT, II, VI-21, s. 193.

48 Zdarzało się wysyłanie deputacji, która miała zmobilizować posłów do wyboru marszałka, jednakże w sytuacji, gdy sejm ewidentnie dogorywał, nie było to racjonalne.

49 APT, II, VI-21, s. 196.

50 DSP, 24.04.

51 APT, II, VI-21, s. 196. 
zatem samą ideę sejmu konnego egzorbitancyjnego, wskazując na prawną niedopuszczalność jego zwołania, zgodnie z żądaniami kontradycentów. Odwołali się tu do trzech argumentów. Przede wszystkim wskazywali na fakt, że sejm z 1698 r. jest sejmem nadzwyczajnym, kontynuującym niejako prace sejmu koronacyjnego. Główne miejsce w tej argumentacji pełnił reces, stanowiący niewątpliwie uchwałę sejmową o mocy równej innym konstytucjom i wymagającym dla swego uchwalenia zgody trzech stanów: „Na seymie coronationis zgodziły się Ordines Rzeczypospolitey na seym Pacificationis, nie na Konny, tedy byłoby to contra communem consensum Rzeczypospolitey"52. Skoro trzy stany na sejmie zgodziły się na zwołanie kolejnego sejmu w określonej formie, to upoważniły monarchę do zwołania go tylko w takiej właśnie formie. Król, nawet gdyby chciał i uznał to za słuszne, nie mógł owej formy zmienić. Zgodę stanów na sejmie koronacyjnym mógł zmienić jedynie actus contrarius - analogiczna zgoda stanów na kolejnym sejmie. Argument ten miał przekonać kontradycentów o swoistej wadzie prawnej ich instrukcji, która stanowiła sprzeciw wobec samej istoty legalnego sejmu i żądała od króla działania sprzecznego z obowiązującym prawem i wolą sejmu. Uzupełnieniem tego stanowiska był kolejny argument senatorów, który osobno podkreślał wagę zgody powszechnej. Senatorowie stwierdzili: „In pactis conventis iest punkt, że consentientibus omnibus maią być wszelkie sancita, a tu non omnes consentiunt, bo tylko kilka powiatów litewskich"53. Powołali się zatem na pakta konwenta, w których rzeczywiście znajdowały się punkty potwierdzające prawo wolnego głosu na sejmie i konieczność uzyskania zgody trzech stanów na sejmie dla stanowienia prawa ${ }^{54}$. Była to sprytna taktyka senatorów, by zawstydzić kontradycentów i postawić ich w niezręcznej sytuacji. Występując bowiem w obronie istotnego z punktu widzenia szlacheckich wolności i praw aktu prawnego, stawiali protestujących posłów w pozycji przeciwników jego respektowania ${ }^{55}$. Ostatni argument senatorów był zdecydowanie najważniejszy. Konstatowali stanowczo: „Prawa nie masz o Konnym Seymie żadnego, chyba niech pozwolą na ten seym, tedy na tym seymie novella lex mogłaby stanąc”. Sejm konny, choć generalnie był konceptem czysto teoretycznym i doktrynalnym, miał swoje miejsce w ustawodawstwie Polski szlacheckiej. Został bowiem wprost ujęty w jednej z klauzul paktów konwentów Augusta II (powtórzonej zresztą potem przez obie redakcje paktów Stanisława Leszczyńskiego oraz w paktach Augusta III ${ }^{56}$. Obowiązywanie paktów

52 DSP, 20.04.

53 Ibidem.

${ }^{54} \mathrm{~W}$ standardowej, rozbudowanej formule zobowiązania do potwierdzenia i respektowania praw Rzeczypospolitej król przysięgał, że będzie „trzymał” konstytucje sejmowe „także y te, które na przyszłey da Bóg Koronacyi, y na drugich Seymach za spólną zgodą wszech Stanów zgodą umówione y postanowione będą", VL, t. VI, s. 24. Jako przejawy tej reguły należy interpretować przepis zakazujący wydawania aktów prawnych leżących w kompetencji sejmu pod pieczęcią pokojową „ex senatus Consilio” czy też zakaz zaciągów cudzoziemskich bez zgody sejmu, ibidem, s. 17.

55 Warto wspomnieć, że w tym argumencie uwidacznia się ciekawe rozumienie paktów. Przecież akt zawarty z przedstawicielami Augusta II został ostatecznie przyjęty i potwierdzony dopiero na mocy konstytucji sejmu pacyfikacyjnego w 1699 r. Obowiązywanie paktów Augusta II przez „pacyfikacją” budziło znaczne wątpliwości. W argumentacji senatorów pakta nie wystąpiły jednak raczej jako konkretna umowa, zawarta z określonym królem - Augustem II. Mowa tu raczej o powtarzalnie odnawianym akcie, który obowiązywał w zasadzie w permanencji. Stąd powołanie na pakta jest tu powołaniem się na długotrwałą tradycję ustrojową.

56 „Seym exorbitantiarum lubo za Antecessorów naszych nie raz bywał na różnych Seymach namówiony, ale aż dotąd dla przeszkód zachodzących prementibus belli motibus, nie przyszło do niego, tedy pro 
konwentów Augusta w 1698 r. (tzn. przed ich ostatecznym ratyfikowaniem i przed akceptacją ,,pacyfikacji”) było wątpliwe nawet dla ówczesnych zwolenników nowego monarchy. Zakładając, hipotetycznie, ryzykownie ich obowiązywanie, przewidywały one wprost, że to król mógł zwołać sejm konny wyłącznie na podstawie osobnej „zgody stanów", a zatem - ze specjalnym upoważnieniem uprzedniego sejmu, którego w 1698 r. niewątpliwie nie było ${ }^{57}$.

Posłowie, którzy pozostali w izbie poselskiej (poza motywowaniem marszałka do kontynuowania obrad), poruszali w swoich dyskusjach problem zasadności zwoływania sejmu konnego w świetle konieczności naprawy egzorbitancji po zakończonym właśnie bezkrólewiu, a nie jego legalności. Szczególnie mocno podkreślali, że sejm w takiej formie jest zbędny dla samej idei przeprowadzenia koekwacji praw. Uznawali, że nie ma potrzeby odwoływania się do nadzwyczajnych środków w celu jej przeprowadzenia, skoro zapadła na nią zgoda na sejmie elekcyjnym i zaakceptował ją sejm koronacyjny. Zapewniali przy tym, że nie istniała i nie istnieje jakakolwiek opozycja wobec tych regulacji. Jeden z posłów wprost dziwił się na sesji 17 kwietnia: „nie masz żadney contradictiey ratione coequatiey [...] na cosz tedy namagaią się tak fervide konnego seymu" 58 . Istotnym argumentem podnoszonym w izbie poselskiej było podkreślanie, że sejm pacyfikacyjny jest jednocześnie egzorbitancyjnym, tzn. powołanym do likwidacji nadużyć i nieprawidłowości w funkcjonowaniu organów państwa. Taki status nadawała mu zresztą uchwała sejmu koronacyjnego ${ }^{59}$. Był to refleks ogólniejszej argumentacji, że sejm pacyfikacyjny jest ze swej istoty szczególnie powołany do naprawy egzorbitancji, gdyż odbudowanie prawdziwej wspólnoty jest możliwe tylko na gruncie respektowania systemu prawnego Rzeczypospolitej, pod warunkiem eliminacji nadużyć prawnych ${ }^{60}$. Najpełniej to stanowisko wyraził oczywiście Szczuka, który zarzucił kontradycentom niezrozumienie istoty sejmu pacyfikacyjnego. Jego zdaniem, że:

subsidio Praw Swobód y wolności, tudzież pro medela exorbitantiarum Status tey Rzpltey Seym trzeci ordynaryjny in casu summe et urgentis necessitatis konny za zgodą wszech stanów Rzeczypospolitey złożyć obiecujemy, na którym szlachta propter tuenda iura sua et immunitates sub poenis de expedicione bellica sancitis stawić się viritim powinni”, VL, t. VI, s. 23, por. AGAD, dz. VI, nr II-49, s. 40.

57 Ciekawa jest opinia kończąca stanowisko senatorów na temat niedopuszczalności sejmu konnego. Wskazują oni na dużą elastyczność systemu prawnego dawnej Polski. Dopuszczają możliwość zwołania sejmu konnego jako sejmu nawet nadzwyczajnego, czyli modyfikację reguły z paktów konwentów zwykłą konstytucją sejmową, por. DSP, 20.04. Analogiczne stanowisko zostało użyte również przez deputację do kontradycentów wysłaną 16 kwietnia, której członkowie po powrocie do izby thumaczyli „I to exposuimus Ichmciom, ze Seym Konny niemoże być, aż stanie pierwey uniwersalna ichmciów zgoda wszystkich woiewództw per constitutionem, ale y tym nie mogliśmy Ichmciów wrócić do Izby naszey”, BO, 652, k. 150. Zgodnie ze stanowiskiem posłów pozostających w izbie poselskiej 24 kwietnia „Z tym się tedy rozeszli potior pars niepozwalaiąc na konny seym mówiąc, że ullatenus bydź niemoże sine tribus ordinibus", APT, II, VI-21, s. 197. Co ciekawe, w trakcie obrad pojawiły się obawy, by król nie ugiął się pod presją protestacji sejmowej i nie zdecydował się na zwołanie sejmu konnego wyłącznie na podstawie konkluzji rady senatu, czyli bez zgody sejmu, „IMość sędzia liwski intulit, aby seym konny nie był wydawany ex senatus Consilio”, DSP, 24.04 .

58 APT, II, VI-21, s. 197.

59 Reces seymu coronationis, VL, t. VI, s. 12-13.

60 Szerzej zob. W. Stanek, Sarmacka idea pacyfikacji wewnętrznej i jej kryzys w XVIII w. [w:] BarokSarmatyzm - Psalmodia. Materiały z konferencji zorganizowanej przez Zakład Historii Nowożytnej, Toruń, 22-23 września 1993, red. K. Maliszewski, K. Obremski, Toruń 1995, s. 99-112. 
stan naszey Rzplitey zły iest, pokazuią domowe diffidencye, rozróżnione affecta, pokazuią puste ławy. IchPP Litewscy dopominają się seymu exorbitantiarum, a cóż iest inszego Seym Pacificationis, na który zjechaliśmy się sanere vulnera Reiplcae ${ }^{61}$.

W refleksji posłów w zasadzie pominięto trudności praktyczne związane z sejmem konnym. Lekceważono duże prawdopodobieństwo wystąpienia aktów przemocy, przy ogromnej frekwencji i militarnym charakterze sejmu konnego (do którego najistotniejszych cech należało przecież odbywanie obrad w polu, w pełnym rynsztunku wojennym). Nie zwracano szczególnej uwagi na fakt, że sejm konny musiałby się odbyć poza standardowym i uświęconym zwyczajem miejscem obrad sejmowych - salami zamku w Warszawie. Ślad tych problemów znajdujemy jedynie w głosie posła trockiego Władysława Michała Turłaja, który „o seymie konnym powiedział, że byłaby to consiliorum niezwyczaina iakaś y dziwna methamorphosis, gdyby ie ex sacrario libertatis przenoszono, in campos martios, a zatym byłaby Rzeczypospolita sine lege, bo tam silent leges"62.

Silniej eksponowano problem efektywności. Wszystkie diariusze zadziwiająco wiernie przytaczają pełną zdrowego sceptycyzmu opinię Szczuki, który błyskotliwe zauważał: „,dopominają się Ichmć seymu konnego, a na cóż wszak tam na tym by się skończyło co y tu wszak nie zębami końskiemi, ale tymże piórem zakończy się to wszystko"63. Inny poseł komentował niewątpliwie równie przytomnie, że skoro „tu nas niewielu a nie zgadzamy się", to sejm konny przy znacznie większej frekwencji całej szlachty musiałby mieć ogromny problem z osiągnięciem zgody wymaganej do powzięcia uchwał - ,in tanto numero et confusione nastąpi większe incitamen”. Podawał przy tym obrady zjazdu pod Gołębiem w czasie konfederacji z 1672 r. jako negatywny przykład staropolskiego sejmowania ${ }^{64}$. Większość publicystyki szlacheckiej sprzyjającej sejmom konnym wyszukiwała w tradycji staropolskiej raczej udanych epizodów sejmowania w trybie viritim, np. mityczny rokosz gliniański czy wojna kokosza (która pozwoliła wymóc na królu poszanowanie wolności szlacheckich $)^{65}$. W tym wypadku mamy do czynienia $\mathrm{z}$ arcyciekawym przypadkiem odwrócenia tej argumentacji i napiętnowania nieskutecznego zjazdu.

Wygłaszane głosy i opinie zmierzały głównie w kierunku walki o trwanie sejmu przez odwlekanie decyzji o jego zakończeniu. Regaliści podejmowali polemikę z tezami kontradycentów i próbowali merytorycznie podważyć fundamenty, na których oparto sprzeciw. Chodziło o to, by osłabić ich upór i przekonać do zmiany postawy w nawiązaniu do staropolskiej „deliberacyjnej” formy sejmowania, polegającej na godzeniu rozbieżnych stanowisk w trybie dyskusji mającej prowadzić do wypracowania konsensu. Żaden z zagorzałych regalistów nie odwołał się jednak do radykalnego, ale i najbardziej

61 BO, 652, k. 150, por. APT, II, VI-21, s. 188.

62 DSP, 17.04.

63 BO, 652, k. 150. Według innej redakcji Szczuka „Seymu konnego nullam necessitatem affirmavit ex aggerando incommoda y że nie zębami końskimi, ale piórem prawa pisać potrzeba y że per pacificationem admissam magna pars exorbitantiarum uprzątnie się”, APT, II, VI-21, s. 190. Notabene, podobnie o sejmie konnym pisał Stanisław Konarski, przytaczając opinię biskupa krakowskiego Konstantego Szaniawskiego o sejmie konnym: „nie wiem, co ten sejm konny lepiej nam poradzi, co to lepiej zrobią końskie niż nasze głowy", cyt. za: H. Olszewski, Sejm ..., t. 2, s. 252.

${ }_{64}$ APT, II, VI-21, s. 198.

65 Por. T. Kucharski, Instytucja egzorbitancji..., s. 286-287. 
oczywistego w zaistniałych okolicznościach argumentu - zakwestionowania samej ważności i legalności zgłoszonego przez Litwinów sprzeciwu. Od samego początku został on uhonorowany jako zgłoszony ,przy prawie”, a wszystkie polemiki z kontradycentami miały na celu wyłącznie przekonanie ich do merytorycznej zmiany zdania. Stało się tak pomimo formalnej niedopuszczalności spełnienia postulatu zwołania sejmu konnego bez zgody wszystkich stanów i pomimo faktu, że posłowie przejechali na sejm z niedopuszczalnym żądaniem bezwarunkowego ,unieważnienia” prawidłowo zwołanego sejmu. W gruncie rzeczy nie dopuszczano nawet myśli o formalnym zlekceważeniu sprzeciwu i uznaniu, że sejm ma pełną activitas. Było to bardzo widoczne w trakcie obrad, na pierwszej sesji po zgłoszeniu sprzeciwu nie wyrażano jakichkolwiek wątpliwości co do skuteczności wprowadzenia obrad w stan passivitas ${ }^{66}$. Gdy 20 kwietnia chorąży nadworny litewski postawił ogólnikowy postulat „uskromienia protestantów y uskromienia szkodliwych niechęci”, przez współdziałanie marszałka i króla, większość posłów zinterpretowała tę opinię - chyba wbrew intencjom jej autora - jako chęć podważenia wolnego sprzeciwu. Spotkało się to ze stanowczą naganą ogółu posłów: „,temu obstiterunt, bo by to [...] było cum praejudicio vetandae vocis albo usurpandae per vim activittis" ${ }^{67}$. Jak prosto thumaczył marszałek Zawisza, uszanowanie kontradykcji: ,„...] iest osobliwa wolnego głosu praerogativa ius vetandi, którą przodkowie nasi do tych czas zachowali" ${ }^{6}$. Jako kwestionowanie samego sprzeciwu można by ewentualnie interpretować jedynie sceptyczną opinię posła Turłaja, który „o przysiędze IchMościów Panów Witebskich Posłów powiedział, że takowe juramentum nie powinno Ichmosciów obligować, ad parricidum Patriae, y iest cale dispensabile, bo Deus non est causa mali" ${ }^{69}$. Nie jest to jednak wbrew pozorom par excellence zakwestionowanie dopuszczalności czy legalności samego sprzeciwu. Poseł twierdził tylko, że bez naruszania sumienia i bez narażania się na odpowiedzialność prawną kontradycenci mogli, mimo złożonej przysięgi, odstąpić od swojego protestu ${ }^{70}$. Mamy tu do czynienia z próbą zbagatelizowania unikatowości sprzeciwu i wpisania go w schemat standardowego użycia ius vetandi na staropolskim sejmie.

Wszystkie przytoczone powyżej głosy stanowią oczywiście typową dla staropolskiego dyskursu próbę wykorzystania przez stronnictwo regalistyczne argumentacji prawni-

66 „Controversia” o activitas związana z małą frekwencją na sejmie miała być poddana pod dyskusję według diariusza wrocławskiego na samym początku sesji pierwszego dnia sejmu, jeszcze przed protestem Litwinów, BO, 652, k. 149v. Zakończyła się ona zapewne oczywistym skonstatowaniem braku określenia wymaganego na obradach kworum, prace izby kontynuowano bowiem według standardowych zasad. W zakresie postulatów zlekceważenia sprzeciwu posłów litewskich znalazłem tylko jedną wypowiedź, z 22 kwietnia. Głos zabrał wówczas „Imć P. sędzia Lwowski upraszając, aby się nie rozieżdżać ob periculam stracenia tey Izby ex ratione, iż protestantes będąc extra activitationem odbierać onymże”, ibidem, k. 152. Jest to w zasadzie twierdzenie, że taki, a nie inny protest nie mieści się w przyjętych normach i dlatego należy „odebrać activitatem" kontradycentom, czyli w zasadzie pozbawić ich mandatu. Znamienne, że głos ten zanotowano tylko w jednym diariuszu i nie spotkał się on z żadnym komentarzem, nie przyniósł też jakichkolwiek skutków. Była to zresztą propozycja nie tyle nieuznania sprzeciwu, ile jego ,uchylenia”. Poseł zgłosił tę propozycję dopiero tydzień po pierwotnym sprzeciwie Litwinów, co świadczy o jego politycznym zabarwieniu.

67 Ibidem, k. 151.

68 Ibidem, k. 150.

69 DPS, 16.04.

70 Turłaj odwołuje się tu zresztą do argumentacji w zupełnie nietrafnej analogii do posłów obligowanych instrukcjami do niewyrażania zgody na prolongację, ibidem. 
czej, pomieszanej z opiniami stricte politycznymi. Wyrażały one skomplikowane stanowisko wymagające poszanowania dla wolnego „nie pozwalam” z jednej, a chęcią ratowania sejmu pacyfikacyjnego $\mathrm{z}$ drugiej strony. $\mathrm{W}$ ostatecznym rozrachunku dowodzą one jednak zupełnej bezradności regalistów wobec stanowczości i konsekwencji kontradycentów. W rezultacie nawet sprzeciw ekstremalnie nietypowy (niemający podstaw prawnych ani faktycznych) nie zdołał skłonić szlacheckiej opinii publicznej do jego odrzucenia. Oczywista nieprawidłowość twierdzeń kontradycentów litewskich, a także nielegalność i nieracjonalność ich postulatów nie stały się przyczyną zablokowania lub nieuznania sprzeciwu. Niedopuszczalność sejmu konnego w świetle recesu sejmu koronacyjnego, niecelowość zarzutów o próbie wzruszenia przez kogokolwiek uchwalonej na sejmie elekcyjnym koekwacji czy niemające prawnego uzasadnienia kwestionowanie formy zwołania sejmu wynikającej z recesu sejmowego i uniwersału monarszego nie stanowiły dla posłów dostatecznego zestawu powodów, by nie uznać sprzeciwu wynikającego z wolnego szlacheckiego głosu na sejmie. Posłom i senatorom pozostało jedynie odwołanie się do tradycyjnych metod - negocjacji z kontradycentami i merytorycznej dyskusji na sesjach plenarnych. Instrumenty te okazały się jednak w tym przypadku zupełnie nieskuteczne.

\section{Podsumowanie. Sejm 1698 r. a ewolucja prawa wolnego sprzeciwu w drugiej połowie XVII w.}

Liberum veto w staropolskim systemie ustrojowym i praktyce parlamentarnej nie może być postrzegane wyłącznie z perspektywy precedensu z 1652 r. Jego rozwój należy raczej widzieć jako długotrwały proces, który kształtował się na przestrzeni całego XVII w. Drogę tę rozpoczyna seria sejmów niedoszłych, bezpośrednio poprzedzających rokosz Zebrzydowskiego, oraz silnie zakorzeniająca się za panowania Zygmunta III praktyka blokowania obrad z powodu postulatów pojedynczych sejmików. Kamieniem milowym było oczywiście zerwanie sejmu przez posła Sicińskiego w 1652 r., jednak dopiero w 1669 r. uznano, że sejm można zerwać jeszcze przed konkluzją sejmową. Rok 1688 przyniósł kolejną przełomową decyzję o dopuszczalności zerwania sejmu, który właściwie nie rozpoczął jeszcze swoich właściwych prac, ponieważ nie zdołał przeprowadzić wstępnych czynności formalnych: elekcji marszałka i weryfikacji poselskich mandatów - czyli rugów. Ważny stawał się sprzeciw posła, którego mandat nie został jeszcze prawidłowo zweryfikowany, na sejmie, który nie uzyskał jeszcze mocy do podejmowania uchwał. Ostatnim akordem na tej drodze, niezauważanym jak dotąd, był właśnie opisywany powyżej sprzeciw na sejmie pacyfikacyjnym z $1698 \mathrm{r}$. Doszło tu do ostatecznego zerwania $\mathrm{z}$ formułowanymi w drugiej połowie XVII w. teoriami próbującymi ustanowić warunki legalnego sprzeciwu ${ }^{71}$. Uznano ostatecznie, że nie istnieje jakakolwiek tama dla wolnego „nie pozwalam”. Nawet zaprzeczenie samej istoty mandatu

71 Na temat formy, zakresu, podstaw prawnych i możliwości kwestionowania protestów w czasach Jana III pisze szeroko R. Kołodziej, ,, Ostatni wolności naszej klejnot”..., s. 424-438. 
posła i bezwzględny nakaz zerwania sejmu, na podstawie ewidentnie sprzecznych z prawem przesłanek, nie mogły doprowadzić do unieważnienia protestu kontradycentów.

Sejm 1698 r. jest w pewnym sensie przełomowy właśnie dlatego, że stanowi najbardziej jaskrawy przykład już nie kryzysu, ale zaniku „deliberatywnego” rozumienia zasady zgody. Okazało się bowiem, że w gruncie rzeczy nielegalny i bezpodstawny protest został przyjęty $\mathrm{w}$ izbie poselskiej. Podejmowane próby polemizowania $\mathrm{z}$ bezwzględnym i umocnionym przysięgą nakazem sejmików, by zerwać sejm, były z góry skazane na niepowodzenie. Sejm walny i jego wewnętrzne procedury oraz cała filozofia szlacheckiego demokratyzmu, która ukształtowała się w toku drugiej połowy XVI i początku XVII w., okazały się wobec takiej postawy zupełnie bezradne. Konsekwencją tego stanu rzeczy stanie się pełna atrofia sejmu w czasach saskich. Kryzys - i w końcu zanik - efektywności form negocjacyjnych towarzyszących sprzeciwom sejmowym oznaczał z technicznego punktu widzenia konieczność mechanicznego respektowania pojedynczych sprzeciwów. Zupełną fikcją staje się od tego momentu dyrektywa „ważenia”, a nie „liczenia” głosów. Niewykonalne jest „ucieranie” stanowiska kompromisowego przez sejmujących. Dochodzi więc do reinterpretacji zasady zgody, która od omawianego momentu będzie synonimem konieczności uzyskania mechanicznej akceptacji przez wszystkich, a nie elastycznego instrumentu wypracowywania konsensusu i godzenia przeciwstawnych stanowisk. A to w zasadzie wprost oznaczało przyjęcie reguły jednomyślności.

\section{Bibliografia}

\section{Źródła rękopiśmienne}

Archiwum Główne Akt Dawnych, Archiwum Radziwiłłów, dz. II, nr 1850; dz. VI, nr II-49.

Archiwum Państwowe w Toruniu, kat. II, VI-21.

Biblioteka Czartoryskich w Krakowie, rkps. 192, 521.

Biblioteka Ossolińskich we Wrocławiu, rkps. 652.

Biblioteka Raczyńskich w Poznaniu, rkps. 102.

\section{Źródła drukowane i starodruki}

Akta sejmiku podolskiego in hostico 1672-1696, wyd. J. Stolicki, Kraków 2002.

Diariusz sejmu pacificationis zaczętego dnia 16 kwietnia 1698 r., b.m.w., 1698.

Volumina Legum, wyd. J. Ohryzko, t. V-VI, Petersburg 1859.

[Zawisza K.], Pamiętniki Krzysztofa Zawiszy wojewody mińskiego [1666-1721], wyd. J. Bartoszewicz, Warszawa 1862.

\section{Literatura}

Choińska-Mika J., Od zgody wszystkich ku jednomyślności-modus concludendi sejmów polskich za ostatnich Wazów [w:] Vetera Novis Augere. Studia i prace dedykowane Profesorowi Wactawowi Uruszczakowi, Kraków 2010.

Artykuły - Articles 
Dybaś B., Sejm pacyfikacyjny 1699 r., Toruń 1991.

Jarochowski K., Dzieje panowania Augusta II, t. I: Od śmierci Jana III do chwili wstapienia Karola XII na ziemię polska, red. K. Bartel, Oświęcim 2015.

Kołodziej R., Elekcje marszałków poselskich w czasach panowania Jana III Sobieskiego [16761695] [w:] Ustrój - polityka - kultura. Studia ofiarowane Profesor Stefanii Ochmann-Staniszewskiej, red. J. Maroń, R. Kołodziej, Wrocław 2011.

Kołodziej R., „, Ostatni wolności naszej klejnot”. Sejm Rzeczypospolitej za panowania Jana III Sobieskiego, Poznań 2014.

Kołodziej R., Sejm elekcyjny w 1674 roku-precedens w procedurze sejmowej? [w:] Wokót wolnych elekcji w państwie polsko-litewskim XVI-XVIII wieku. O znaczeniu idei wyboru-między prawami a obowiazkami, Katowice 2016.

Kołodziej R., Sejm z 22 grudnia 1693 roku, „Wieki Stare i Nowe” 2016, t. 15.

Kołodziej R., Z najnowszych badań nad parlamentaryzmem szlacheckim Rzeczypospolitej w XVIXVII wieku, „Historia Slavorum Occidentis” 2013, t. 2 (5).

Kołodziej R., Zwierzykowski M., Bibliografia parlamentaryzmu Rzeczypospolitej szlacheckiej, Poznań 2012.

Konopczyński W., Liberum veto. Studium porównawczo-historyczne, red. J. Lohman, Kraków 2002.

Kucharski T., Instytucja egzorbitancji w systemie prawnoustrojowym Rzeczypospolitej Obojga Narodów, Torun 2014.

Kucharski T., ,, Naderwany” sejm konwokacyjny w 1696 r. Uwagi o nieodzowności historii prawa na marginesie pracy Ewy Gąsior [artykuł oddany do druku w „Czasopiśmie Prawno-Historycznym"].

Lewandowska-Malec I., Demokracje polskie. Tradycje - współczesność - oczekiwania, Kraków 2013.

Lewandowska-Malec I., Early Modern Polish Parliamentarism [16 $6^{\text {th }}-18^{\text {th }}$ C.]: Directions of the Newest Research, „Krakowskie Studia z Historii Państwa i Prawa” 2018, t. 11, z. 1.

Lewandowska-Malec I., „Tragedya Conclusyey Seymowey”. Rozważania o formie i materii [w:] Społeczeństwo a władza. Ustrój, prawo, idee, red. J. Przygodzki, M.J. Ptak, Wrocław 2010.

Malec J., Coaequatio Iurium Stanów Wielkiego Księstwa Litewskiego z Korona Polska z 1697 r., „Studia Baltico-Slavica” 1979, t. 12.

Olszewski H., Sejm w dawnej Rzeczypospolitej. Ustrój i idee, t. 1, Poznań 2002.

Paradowski P., W obliczu ,nagłych potrzeb” Rzeczypospolitej: sejmy ekstraordynacyjne za panowania Władysława IV Wazy, Torun 2005.

Rachuba A., Wielkie Księstwo Litewskie w systemie parlamentarnym Rzeczypospolitej w latach 1569-1763, Warszawa 2002.

Seredyka J., Elekcje marszałków poselskich za Zygmunta III Wazy [w:] Studia z dziejów Rzeczypospolitej szlacheckiej, red. K. Matwijowski, Z. Wójcik, Wrocław 1988.

Stanek W., Sarmacka idea pacyfikacji wewnętrznej i jej kryzys w XVIII w. [w:] Barok - Sarmatyzm - Psalmonia. Materiały z konferencji zorganizowanej przez Zakład Historii Nowożytnej, Toruń, 22-23 września 1993, K. Maliszewski, K. Obremski, Torun 1995.

Vitsko Dz., Stanowisko Wiśniowieckich wobec sporów o sejm konny w 1698 roku [w:] Kultura parlamentarna epoki staropolskiej, red. A. Stroynowski, Warszawa 2013.

Wojtasik J., Walka Augusta II z obozem kontystowsko-prymasowskim w pierwszym roku panowania [1697-1698], „Przegląd Historyczny” 1969, t. 60, z. 1. 